\title{
Hadith about Educational Curriculum
}

\author{
Darliana Sormin \\ University of Muhammadiyah Tapanuli Selatan, Sumatera Utara, Indonesia \\ darliana.sormin@um-tapsel.ac.id
}

\begin{abstract}
Education is a conscious effort made by humans to humanize humans. This is done in order to empower all potential so that human beings are in accordance with their nature. Human nature, nowadays, is increasingly marginalized by worldly forms. At its culmination point, humans no longer understood their nature as Caliph fi al-ardh which coincided with the purpose of the creation of jinn and humans in order to serve the Creator. In line with efforts to humanize humans who have humanized education harmonized with human needs in their time. It is this change in human needs that leads people to keep up to date, which is in line with the times. Because, the age that continues to develop in accordance with rapid civilization can moralize specific needs. Specifications of human needs for material. The higher human intelligence, the more curiosity and the more problems and challenges in life. To answer these problems and challenges, various branches of science were born. Even so, essentially, Islamic Education is the foremost part that must be developed to the root of life's problems. Because, humans who are naturally created by God must remain in the order of life guided by Islam.
\end{abstract}

Keywords : hadith; education curriculum

\section{Introduction}

Prophet's hadith (sunnah) is one of the sources of Islamic truth. While education in Islam is part of the effort to create a human condition in accordance with the advice of the Creator. As an explanation (al-bayan) for the Al-Qur'an, the position of the hadith becomes very urgent to remain an expected part of human progress in following the advice of the Creator.

Education is a conscious effort made by humans to humanize humans. This is done in order to empower all potential so that human beings are in accordance with their nature. Human nature, nowadays, is increasingly marginalized by worldly forms. At its culmination point, humans no longer understood their nature as Khalifah fi al-ardh which coincided with the purpose of the creation of jinn and humans in order to serve the Creator.

In line with efforts to humanize humans who have humanized education harmonized with human needs in their time. It is this change in human needs that leads people to keep up to date, which is in line with the times. Because, the age that continues to develop in accordance with rapid civilization can moralize specific needs. Specifications of human needs for material. The higher human intelligence, the more curiosity and the more problems and challenges in life. To answer these problems and challenges, various branches of science were born.

Even so it is essentially, Islamic Education is the foremost part that must be developed to the root of life's problems. Because, humans who are naturally created by God must remain in the order of life guided by Islam. Because, Islam is an instrument that synergizes all human needs.

Functional Islamic education is the effort of Muslim humans to manipulate the formation of al-Kamil through the creation of a conducive educational situation I. In the 
context of manipulating the creation of al-Insan al-Kamil, the curriculum concept was raised. The curriculum is structured as part of human needs to make life in education easier.

The urgency of this discussion was carried out in order to find several references that could be developed to condition Islamic education. Because, so far education is more oriented towards the west. In this connection the title of this paper is discussed.

\section{Review of Literature}

\subsection{Understanding of Education Curriculum}

Functional Islamic education is an attempt by Muslim humans to engineer the formation of al-insan al-kamil through the creation of conducive educational interaction situations. In this position, Islamic education is the most effective individual and social engineering model for preparing and creating the ideal form of society into the future. In line with the ummah's future engineering concept, Islamic education must have a set of contents or materials that will be transformed to students to become their own and their personalities in accordance with Islamic ideals. For this reason, it is necessary to design a form of Islamic education curriculum that fully refers to fundamental values Islamic teachings. ${ }^{1}$

Therefore, the curriculum is a very important factor in the educational process in an Islamic Education Institution. All things that must be known or impregnated and internalized by students must be determined in the curriculum. Also all the things that must be taught by educators to their students must be explained in the curriculum.

Thus, the curriculum clearly illustrates how and what must happen in the teaching and learning process carried out by educators and students. So, the curriculum describes teaching and learning activities in an educational institution. ${ }^{2}$

As a terminology in general, the curriculum is always interpreted as the scope of learning. There are several terminoli offered by experts according to their fields. The curriculum is etymologically, originating from Greek, curling which means runner, and curer means the distance that must be traveled by runners. Thus, in the context of education, it is interpreted as a circle of instruction which is a circle of teaching where the teacher is involved. ${ }^{3}$

In Arabic, the term curriculum is called manhaj al-dirasat which means a bright path, or a path that is passed by humans in various fields of life. This understanding in the field of education, which is meant by manhaj, is as a bright path that is passed by educators or teachers to train with people who are educated or put in place to develop their knowledge, skills and attitudes. ${ }^{4}$ More easily understood, Al-Syaibany explained that the curriculum is a number of strengths, the natural factors surrounding teaching and education provided by the school for students in and outside it, with a number of experiences born of interactions with forces and factors. that factor.

\footnotetext{
${ }^{1}$ Al-Rasyidin, Nizar Samsul, Filsafat Pendidikan Islam, (Jakarta: Ciputat Press, 2005), p.55

${ }^{2}$ Muzayyin Arifin. Filsafat Pendidikan Islam. ( Jakarta: PT Bumi Aksara, 2010), p. 77

${ }^{3}$ Samsul Nizar, Filsafat Pendidikan Islam, Pendekatan Historis, Teoritis, dan Praktis (Jakarta: Ciputat Press, 2002), p. 56

${ }^{4}$ Omar Muhammad Al-Thoumy Al-syaibany, Falsafah Pendidikan Islam (Jakarta: Bulan Bintang, 1979), p. 478 
The curriculum is a very decisive component in a system in education, therefore the curriculum is a tool to achieve educational goals and at the same time as a guide in the implementation of teaching on all types and levels of education. ${ }^{5}$ Functionally, according to Ramayulis ${ }^{6}$, which was followed by Muhaimin and Abdul Mujib, it was categorized as a study program, content, planning activities, learning outcomes, reproduction, cultural, learning and production experiences. Whereas according to Hery Noer Ali, the curriculum is an educational plan that provides technical guidelines, scope, and order of content and process of education. ${ }^{7}$

Another opinion, as stated by Oemar Hamalik ${ }^{8}$, states that the curriculum is a set of plans and arrangements regarding the content and material of learning and the methods used as guidelines for the implementation of educational units in order to achieve educational goals. Practically the curriculum is an educational plan that provides guidance on the type, scope, and process of education. Simply stated, that the curriculum is an educational program that provides to teach students consisting of a series of learning experiences and in which there are a number of subjects that must be taken and studied by students in a certain time to obtain a number of knowledge and marked by the acquisition of a certain diploma.

If it is associated with Islamic education, the curriculum is prepared to realize Islamic education by paying attention to the development stage of students and their suitability to the environment, the development needs of the whole Muslim people, the development of science and technology. Substantially, according to Ali Al-Jumbulati, ${ }^{9}$ the Islamic education curriculum is different, although they agree that the holy book of Al-Qur'an remains another source of study.

As stated by M. Arifin ${ }^{10}$, curriculum is an important factor in the learning process in an Islamic educational institution. Everything that must be known, understood, lived, and experienced by students must be determined in the curriculum. Also all things that must be determined by students, must be described in the curriculum. Thus the Islamic education curriculum is not only an elaboration of a series of sciences that must be taught, but also educational activities that are deemed necessary to have an influence on students in order to achieve the goals of Islamic education.

Of the several definitions stated above, in connection with the discussion topic in this paper, a series of learning materials must be included in educational units to become material. Thus, in fact, etymological derivation of the meaning of the curriculum is interpreted as a circle of teaching in which teachers and students are involved in $\mathrm{it}^{11}$, the scope of the curriculum is very broad. Now it depends on how the management is carried out so that it is in line with what is expected. So that there can be differences in the orientation of one educational institution with other educational institutions.

\footnotetext{
${ }^{5}$ Ramayulis, Ilmu Pendidikan Islam (Jakarta: Kalam Mulia, 2002), p. 127

${ }^{6}$ Ibidh, p. 129-130.

${ }^{7}$ Heri noer Ali, Ilmu pendidikan Islam (Jakarta: Logos, 1999), p. 161

${ }^{8}$ Oemar Hamalik, Kurikulum dan Pembelajaran (Jakarta: Bumi Aksara, 1999), pp. 16-19

${ }^{9}$ Ali Al-Jumbulati, Perbandingan Pendidikan Islam, translated by M. Arifin (Jakarta: Rineka cipta, 1994), p. 58.

${ }^{10}$ M. Arifin, Filsafat Pendidikan Islam (Jakarta: Bumi Aksara, 2000), p. 85.

${ }^{11}$ Al-Rasyidin dan Nizar, Filsafat Pendidikan Islam, p. 56 


\subsection{Hadits About Education Curriculum}

The main foundation of Islamic education is the Qur'an. Whereas the Sunnah (hadith of the prophet) as the second source of truth is the most important part of the education process. The Qur'an and the Sunnah of the Prophet are the most important parts in the context of Islamic education. This is useful so that the values of education cannot be separated from the Islamic system. But in this study, this hadith is considered important considering that most of the hadiths are operational, because of the main function of the hadith of the Prophet Muhammad. is as an explanation (al-bayan) of the verses of AlQuran. ${ }^{12}$ Furthermore, the main function of the Sunnah is an explanation of the verses of the Qur'an which need it. ${ }^{13}$ Thus, hadiths have a vital urgency in reinforcing curriculum content which will be discussed in the next article.

\section{Discussion}

Furthermore, semantic curriculum derivation is meant as a circle of teaching where the teacher and students are involved, ${ }^{14}$ the scope of the curriculum is very broad. Now it depends on how the management is done so that it is as expected. So that there can be differences in the orientation of one educational institution with other educational institutions.

The Islamic education curriculum is also oriented towards:

- Educational Faith (tauhid / akidah),

- Moral Education (Psychology),

- Physical education,

- Intellectual Education (reason),

- Social Education

To be able to meet all dimensions of the Islamic education curriculum, the ability to choose priority material in the learning process is needed.

\subsection{Educational Faith (Tawhid / Akidah)}

Educational Faith (Tawheed / Akidah) is education that binds children with the basics of faith, pillars of Islam, and the basics of shari'ah, since children begin to understand and can understand something. What is meant by the basics of faith is everything that is determined through the news correctly without changing the nature of the faith, and unseen problems, such as believing in Allah, believing in angels, believing in divine books, believing in all the Apostles, believing that humans will be questioned by two angels, believing in the torment of the grave, the day of resurrection, reckoning, surge, hell, and all other supernatural matters. ${ }^{15}$ Faith education (tauhid / akidah) aims to establish religious beliefs and beliefs through the mind, in addition to the stability of the heart, which is based on revelation. The Source of Faith (tauhid / akidah) is that the Qur'an and Hadith contain a lot of the manifestations of Allah SWT, His unity, His character, and other issues of faith (tawhid / akidah).

\footnotetext{
${ }^{12}$ Nawir Yuslem, Ulumun Hadist (Jakarta: Mutiara Sumber Widya, 2003), hal. 69.

${ }^{13}$ Ramli Abul Wahid, Study Ilmu Hadist (Bandung: Ciptapustaka Media, 2005), p. 44

${ }^{14}$ Al-Rasyidin dan Nizar, Filsafat, p. 56.

${ }^{15}$ Abdullah Nashih Ulwan, Tarbiyah al-aulad fil islam (Al-Iskandariyah: Darussalam, 2005), juz 1 p. 117
} 
Like the hadith of Bukhari no. 48 narrated by Abu Hurairah Ra:

$$
\begin{aligned}
& \text { عن أبي هريرة قال كان النّيّ صلّ الله عليه وسلّم بارزايوماللناس فأتاه جبريل فقال باله إيمان قال } \\
& \text { ال إيمان أن نؤمن بالّه وملاعك ته ونكتبه وبلقاءه ورسله وتؤمن با لبعث قال باا ل إسلام } \\
& \text { قال بال ل إسلام أن تعبدالله ولاتثرك به شيأ وتقيم الضلاة وتؤدي الزّكاة أمفرو ضة وتصوم } \\
& \text { رمضان قال ما الإحسان قال أن تعبد الله كأنك تراه فإن لم تكن راه فإنّه يراك قال متى السّاعة } \\
& \text { قال مالمدؤل عنها بأعلم من الساءل وسأخبرك عن شراطهإذاولدت الإمة ربهاواذاتطاول رعاة الإ } \\
& \text { بل الب هم م في البنيان خمى لا العلمهن إلا اللهثّ تلا النبيّ صلى الله عليه وسلّم انّ الله } \\
& \text { عنده علم الساعة الآية ثم دبرفقال ردّوه فلم يروا شيمًا فقال هذا خبريل جاء يعلم الناس دينهم. }
\end{aligned}
$$

The above hadith in the context of naming faith (tauhid / akidah), this is very important considering the many issues of tauhid that are not strong enough to be instilled in the hearts of students or the next generation. Without that, the values of Islam will disappear from the face of the earth, so it needs to be reminded that students or future generations remain consistent with the strength of faith (tauhid / akidah).

\subsection{Moral Education (Psychology)}

In Islamic morality occupies an important position, this can be understood from one of the mission of the Prophet Muhammad SAW sent by God in the world is to perfect human morals. And the Prophet Muhammad SAW himself was an exemplary example in all aspects of life which included dimensions of affection, cognition, and psychomotor. From the perfection of moral education (psychology) this covers the totality of the basics of human development in all dimensions. In line with the mission of carrying out the mission naming noble character, the Prophet Muhammad SAW always preached moral (psychological) glory as in the hadith:

$$
\begin{aligned}
& \text { حدثثنا و كيع قال حدثثنا حمّاد بن سلمه عن محمّد بن زيادعن آبي هريرة عن النّيّ صلى اللّّم عليه و } \\
& \text { سلمّ قال خير كُ في الإسلام أحاسنكم أخلاقا إذا فقهوا. }
\end{aligned}
$$

The above hadith is clear that the Prophet Muhammad emphasized the importance of the necessity for every Muslim to have a noble character. Naturally humans have imitating properties, if the community where the living child holds the moral principle begins, then this will give birth to intrinsic motivation in each Muslim individual. With this example of noble character will be the basis of learning that must be owned by every Muslim to develop good morals in any situation or condition.

Moral education is related to psychologically important given to children to achieve a healthy soul. In this education the role of the family is important, because the family is involved in the life of the child from the beginning of his life until then he has his own 
household. ${ }^{16}$ With this moral education it is expected that children will be able to achieve healthy mental and emotional development, including loving all creatures of Allah SWT. Therefore Islam is a religion with a set of rules and norms that must be adhered to by its adherents. So, the planting of teachings and Islamic values from an early age to students or the next generation is an absolute.

\subsection{Physical education}

Education in general is directed at efforts to develop affective, cognitive, and psychomotor aspects in students. In order to achieve these three goals in a balanced manner, a balance is needed in their physical and mental development as well as their soul.

Two aspects that require attention and development in education are physical and psychological aspects. In connection with this, the path taken is to equip students with good physical education. In the school and madrasah curriculum, physical education is always associated with health, so it is often accustomed to being Penjaskes (Physical and Health Education) or Orchestra (Sports and Health). In the early stages of education in elementary school, peer learning about physical (physical) education has established efforts to fertilize the values of sportsmanship, honesty, cooperation, tolerance, and confidence in the physical application of subjects in the form of simple basic games and movements. ${ }^{17}$

Physical education in general aims at forming people who are physically and mentally healthy, creating physical fitness, a means of developing achievement.

It is undeniable that the Prophet Muhammad SAW ordered his people to maintain health and physical fitness through physical education, although not in the formal sense as contained in the curricula about physical education, as well as spiritually healthy, are the same. Even a number of worship services in Islam are physically strong to carry it out. Guidelines for the importance of health, among others, are obtained through bodily cleanliness, because the pillar of worship in Islam is "Prayer" can only be carried out after going through a series of cleansing processes, namely "Wudu". This command of purifying oneself is clearly very much related to the demands of physical (physical) hygiene, which in turn becomes a prerequisite for the health of individuals. There are countless rules, rules, and procedures for achieving physical cleanliness in Islam summarized in Thaharah, which shows how Islam strongly demands the cleanliness of the people. ${ }^{18}$ Without it, prayer is clearly invalid, according to the word of Allah SWT at the end of verse 108 in Surah Al-Taubah:

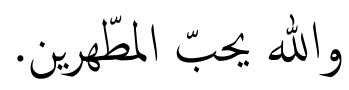

Meaning: "And indeed Allah likes those who cleanse themselves."19

\footnotetext{
${ }^{16}$ Hasan Langgulung, Manusia dan pendidikan: Suatu Analisa Psikologi dan Pendidikan (Jakarta: Al-Husna, 1986), pp. 84-85.

${ }^{17}$ Pusat Kurikulum Balitbang Depdiknas, Model pembelajaran Tematik Kelas Awal Sekolah Dasar, pp. 32

${ }^{18}$ Cited from Al-As'ilah wa Al-Fiqhiyyah Al-Maqrunah bi Al-Adillah Asy-Syar'iyyah jilid 1, Disalin ulang dari Majalah Fatawa 03/1/Dzulqa'adah 1423H-2002M dalam http://www.almanhaj.or.id.

${ }^{19}$ Al-Qur'an Al-Fatih (Jakarta: Insan Media Pustaka, 2013), p. 204. 


\subsection{Intellectual Education (Reason)}

Given its function as Bayan Al-Qur'an, the study of intellectual educational traditions (reason). This is directed and intended to explain the concept of qaql in the Qur'an. Of the 49 verses of the Qur'an which contain the words 'aql and their derivatives are almost entirely in the form of active verbs. ${ }^{20}$

The word sense has become Indonesian which comes from the Arabic word in the form of a noun. Al-qAql means understanding or understanding, besides that Al-'aql means Alhijir which is to hold back and curb lust. Then also explained that Al-qaql means wisdom, the opposite of weak mind. Al-'aql also means heart. ${ }^{21}$

In the human body, there is something that always experiences dynamics in its interactions with the creators of nature, humans and nature itself. That is reason. The discussion of reason has been going on for a long time. During that evolution thought and understanding of what is meant by reason, existence and function in human life. The root of history which is noted to be the starting point for the growth of the use of reason is the Mesopotamian Egyptians around 5,000 BC-4,000 BC. went to ancient Greece with the phenomenal figure Plato (427-347) BC placed reason as a human compass in understanding this world, while Aristotle saw reason as activeness for growing and vegetative, moving, and thinking. John Dewey (1859-1952) adherents of the paragmatic school, placed reason as a human tool to adapt to the surrounding natural environment and the tools in charge of thinking. ${ }^{22}$

In Islamic education the functioning of reason experiences dynamics and ups and downs. And what is recorded today is the phenomenon of mindless activity. Thus every educational institution and individuals involved in the world of Islamic education must form a solid and strong team in the framework of creating a mechanism for this resource education project.

One of them is by conducting a study focusing on the epistemology of Islam and by activating research curricula in various scientific fields and so on, good intentions and determination are needed in this regard.

\subsection{Social Education}

Social science is a number of studies that use scientific methods in studying various kinds of activities made by humans as done by an individual, or a group of people.

\section{Conclusion}

Functional Islamic education is an attempt by Muslim humans to engineer the formation of al-Insan al-Kamil through the creation of conducive educational interaction situations. In this position, Islamic education is the most effective individual and social engineering model for preparing and creating the ideal form of society into the future.

\footnotetext{
${ }^{20}$ Baharuddin, Paragdima Psikologi Islam (Yogyakarta: Pustaka Pelajar, p. 117.

${ }^{21}$ IbnuManzur, Lisan Al-Arab, juz 3, p. 485.

${ }^{22}$ Muhaimin dan Mujib, Pemikiran Pendidikan Islam (Bandung: Trigenda Karya, 1993), p. 42.
} 
The curriculum is a very important factor in the educational process in an Islamic Education Institution. All things that must be known or impregnated and internalized by students must be determined in the curriculum. Also all the things that must be taught by educators to their students must be explained in the curriculum.

Thus, the curriculum clearly illustrates how and what must happen in the teaching and learning process carried out by educators and students. So, the curriculum describes teaching and learning activities in an educational institution.

The main foundation of Islamic education is the Qur'an. Whereas the Sunnah (hadith of the prophet) as the second source of truth is the most important part of the education process. The Qur'an and the Sunnah of the Prophet are the most important parts in the context of Islamic education. This is useful so that the values of education cannot be separated from the Islamic system. But in this study, this hadith is considered important considering that most of the hadiths are operational, because of the main function of the hadith of the Prophet Muhammad. is as an explanation (al-bayan) of the verses of AlQuran. Furthermore, the main function of the Sunnah is an explanation of the verses of the Qur'an which need it. Thus, hadiths have a vital urgency in reinforcing curriculum content which will be discussed in the next article.

Furthermore, semantic curriculum derivation is meant as a circle of teaching in which the teacher and students are involved. hence the curriculum coverage is very broad. Now it depends on how the management is done so that it is as expected. So that there can be differences in the orientation of one educational institution with other educational institutions. Strictly speaking, the Islamic education curriculum is also oriented towards:

- Educational Faith (tauhid / akidah),

- Moral Education (Psychology),

- Physical education,

- Intellectual Education (reason),

- Social Education

\section{References}

Al-Rasyidin, Nizar Samsul. 2005. Filsafat Pendidikan Islam, Jakarta: Ciputat Press. Muzayyin Arifin. 2010. Filsafat Pendidikan Islam, Jakarta: PT Bumi Aksara.

Samsul Nizar. 2002. Filsafat Pendidikan Islam, Pendekatan Historis, Teoritis, dan Praktis, Jakarta: Ciputat Press.

Omar Muhammad Al-Thoumy Al-syaibany. 1979. Falsafah Pendidikan Islam, Jakarta: Bulan Bintang.

Ramayulis. 2002. Ilmu Pendidikan Islam, Jakarta: Kalam Mulia.

Heri noer Ali. 1999. Ilmu pendidikan Islam, Jakarta: Logos.

Oemar Hamalik. 1999. Kurikulum dan Pembelajara, Jakarta: Bumi Aksara.

Ali Al-Jumbulati1994. Perbandingan Pendidikan Islam, terjemahan M. Arifin Jakarta: Rineka cipta.

M. Arifin. 2002. Filsafat Pendidikan Islam, Jakarta: Bumi Aksara.

Nawir Yuslem. 2003. Ulumun Hadist, Jakarta: Mutiara Sumber Widya.

Ramli Abul Wahid. 2005. Study Ilmu Hadist, Bandung: Ciptapustaka Media. 
Abdullah Nashih Ulwan. 2005. Tarbiyah al-aulad fil islam, Al-Iskandariyah: Darussalam.

Hasan Langgulung. 1986. Manusia dan pendidikan: Suatu Analisa Psikologi dan Pendidikan Jakarta: Al-Husna.

Pusat Kurikulum Balitbang Depdiknas, Model pembelajaran Tematik Kelas Awal Sekolah Dasar.

Cited from Al-As'ilah wa Al-Fiqhiyyah Al-Maqrunah bi Al-Adillah Asy-Syar'iyyah. Copy from Majalah Fatawa 03/1/Dzulqa'adah 1423H-2002M in http://www.almanhaj.or.id.

Baharuddin. 2007. Paragdima Psikologi Islam, Yogyakarta: Pustaka Pelajar.

Muhaimin dan Mujib. 1993. Pemikiran Pendidikan Islam, Bandung: Trigenda Karya. 